\title{
CORRIGENDUM
}

\section{A survey of thelotremoid lichens (Ascomycota: Ostropales) in subantarctic regions excluding Tasmania - CORRIGENDUM}

\author{
H. Thorsten LUMBSCH, Pradeep K. DIVAKAR, \\ Marìa Inés MESSUTI, Armin MANGOLD and Robert LÜCKING
}

doi:10.1017/S002428290999048X, Published by Cambridge University Press, 29 January 2010, volume 42(2): 203-224.

In the lectotypifaction of Thelotrema hians Stirt. page 214 (Lumbsch et al. 2010) the collection number of the Buchanan specimen is incorrect; the citation should read 'Buchanan $114 \mathrm{pr}$. P.’.

\section{REFERENCE}

Lumbsch, H.T., Divakar, P.K., Messuti, M.I., Mangold, A. \& Lücking, R. (2010) A survey of thelotremoid lichens (Ascomycota: Ostropales) in subantarctic regions excluding Tasmania. Lichenologist 42: 203-224. 